\title{
Zooplankton community dynamics in relation to the seasonal cycle and nutrient inputs in an urban tropical estuary in Brazil
}

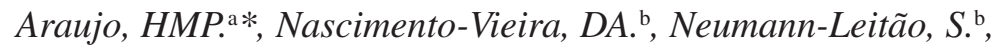 \\ Schwamborn, $R .^{\mathrm{c}}$, Lucas, APO. ${ }^{\mathrm{a}}$ and Alves, $J P H .^{\mathrm{d}}$ \\ aDepartamento de Biologia, Universidade Federal de Sergipe - UFS, \\ Av. Marechal Rondon, s/n, S. Cristóvão, CEP 49100-000, Aracaju, SE, Brazil

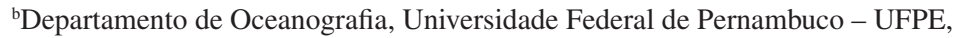 \\ Av. Arquitetura, s/n, Cidade Universitária, CEP 50730-540, Recife, PE, Brazil \\ 'Department of Animal Ecology, Alfred Wegener Institute for Polar and Marine Research - AWI, \\ Am Alten Hafen, 26, D-27568, Bremerhaven, Germany \\ ${ }^{\text {d} D e p a r t a m e n t o ~ d e ~ Q u i ́ m i c a, ~ U n i v e r s i d a d e ~ F e d e r a l ~ d e ~ S e r g i p e ~-~ U F S, ~}$ \\ Av. Marechal Rondon, s/n, S. Cristóvão, CEP 49100-000, Aracaju, SE, Brazil \\ *e-mail: haraujo@ufs.br \\ Received November 28, 2006 - Accepted April 17, 2007 - Distributed November 30, 2008
}

(With 8 figures)

\begin{abstract}
Micro- and mesozooplankton were studied in the Sergipe estuary, northeastern Brazil, in order to assess the temporal variability in abundance and biodiversity under stressed conditions (urban pollution). Zooplankton samples and abiotic data were collected at one station during a full tidal cycle in July 2001 and in February 2002, corresponding to the rainy and dry seasons, respectively. The salinity regime was euhaline-polyhaline. Phosphate and dissolved oxygen were higher in July 2001, and nitrite, nitrate and ammonia in February 2002. Chlorophyll- $a$ concentrations were low as a result of light limitation, with $1.18 \pm 0.88 \mu \mathrm{g} . \mathrm{m}^{-3}$ in February and $1.53 \pm 1.48 \mu \mathrm{g} \cdot \mathrm{m}^{-3}$ in July. Fifty-nine zooplankton taxa were identified. Microzooplankton were abundant, mainly the tintinnid Favella ehrenbergii, and ranged from 18,649 ind. $\mathrm{m}^{-3}$ in July to 678,009 ind. $\mathrm{m}^{-3}$ in February. Mesozooplankton ranged from 1,537 ind. $\mathrm{m}^{-3}$ in July to 37,062 ind. $\mathrm{m}^{-3}$ in February and were dominated by barnacle nauplii in July and by copepods in February. The cluster analysis by taxa revealed the existence of three distinct groups: resilient species, characteristic of estuarine areas and occurring during all the year; species mainly more abundant in July (indicators of a healthier environmental condition); and species more abundant in February (tolerant to poor water quality).
\end{abstract}

Keywords: zooplankton, tropical estuaries, seasonal variability, northeastern Brazil.

\section{Dinâmica da comunidade zooplanctônica em relação a um ciclo sazonal e aportes de nutrientes em um estuário urbano tropical no Brasil}

\begin{abstract}
Resumo
O micro-e o mesozooplâncton foram estudados no estuário do rio Sergipe, Nordeste do Brasil para conhecer a variação temporal em abundância e biodiversidade sob condições de estresse. Amostras do zooplâncton e dados abióticos foram coletados em uma estação durante um ciclo completo de marés em julho de 2001 e em fevereiro de 2002, correspondendo aos períodos chuvoso e seco, respectivamente. O regime de salinidade variou de euhalino a polihalino. O fosfato e o oxigênio dissolvidos foram mais elevados em julho 2001, e o nitrito, o nitrato e a amônia, em fevereiro 2002. As concentrações de clorofila- $a$ foram baixas devido à limitação da luz, com valores médios de $1,18 \pm 0,88 \mu \mathrm{g} \cdot \mathrm{m}^{-3}$ em fevereiro e $1,53 \pm 1,48 \mu \mathrm{g} \cdot \mathrm{m}^{-3} \mathrm{em}$ julho. Foram identificados 59 taxa zooplanctônicos. O microzooplâncton foi abundante, principalmente o tintinídeo Favella ehrenbergii, que variou de 18.649 ind. $\mathrm{m}^{-3} \mathrm{em}$ julho a 678.009 ind. $\mathrm{m}^{-3} \mathrm{em}$ fevereiro. O mesozooplâncton variou de 1.537 ind. $\mathrm{m}^{-3} \mathrm{em}$ julho a 37.062 ind. $\mathrm{m}^{-3} \mathrm{em}$ fevereiro e foi dominado por náuplios de Cirripedia em julho e por Copepoda em fevereiro. A análise de agrupamento por taxa revelou a existência de três grupos: espécies resilientes, características de áreas estuarinas de ocorrência contínua; espécies que dominaram em julho (indicadores de uma melhor condição ambiental); e espécies mais abundantes em fevereiro (tolerantes à baixa qualidade da água).
\end{abstract}

Palavras-chave: zooplâncton, estuário tropical, variação sazonal, nordeste do Brasil. 


\section{Introduction}

The Sergipe estuary is surrounded by Aracaju City (Sergipe State, northeastern Brazil), and as with many other tropical estuaries, is threatened by the diverse uses to which humans put this water body and the land areas that drain into it. Consequently, the estuary has a multitude of environmental problems. The most common are degraded natural habitats, declining plant and animal populations, diminishing fish and shellfish harvests, and impaired water quality (JICA, 1998).

In the estuary, the fresh and more saline waters mix to an extent that depends on conditions in the river, the ocean, the shoreline, and the air, all of which are changing with the tides and seasons. These natural interactions of physical, chemical, and biological factors, combined with the influence of human use, challenge our ability to understand and manage this natural resource.

Zooplankton species are diagnostic in determining the ecosystem quality and they can be quantitatively measured (Maguire, 1973; Resh and Unzicker, 1975; Day Jr. et al., 1989). The zooplankton is also an important intermediate component in estuarine food webs, acting as a trophic link between small organic particles (e.g. detritus and microalgae) and planktivorous fishes (McLusky and Elliott, 2004). The larvae of commercially important fish, shrimp and crab species are part of the zooplankton community (Morgan, 1990).

Knowledge of the variability of the estuarine zooplankton composition and abundance at different temporal scales is a prerequisite to the understanding of the ecosystem dynamics. In estuaries the temporal variation in environmental conditions strongly affects the distribution of zooplankton species (Dauvin et al., 1998). Since the most important factor affecting variability in mesoand macrotidal estuaries is the tide, accuracy in estimates of the zooplankton requires sampling over a 24 hours period (McLusky and Elliott, 2004).

One question to be addressed in this study is whether the abiotic phenomena in the Sergipe River estuary (e.g. circulation pattern, tides) and water condition have a relationship with identifiable patterns in the zooplankton assemblages structure.

Despite the ecological and social importance of the Sergipe River estuary, few investigations of its zooplankton community have been published: Forneris et al. (1977) on taxonomic composition; Araújo (1982) on qualitative and quantitative aspects, with special reference to Hydromedusae; and Rocha (1978) and Nascimento and Rocha (1994) on general diversity and abundance.

Few studies have been dedicated to the comparison of the temporal variability of micro- and mesozooplankton densities in marine systems (Sorokin, 1995; Gismervik et al., 2002), and even fewer data on the dynamics of these communities are available for tropical estuaries.

The main objectives of the present study were to compare tidal, diurnal and seasonal effects on the vari- ability of the main physico-chemical and biological parameters in the Sergipe River estuary, and to compare the dynamics of micro- and mesozooplankton communities in an extremely eutrophic and variable environment.

\section{Materials and Methods}

\subsection{Study site}

The Sergipe River rises in Bahia State and flows $140 \mathrm{~km}\left(10.8^{\circ}, 11.0^{\circ} \mathrm{S}\right.$ and $\left.37.2^{\circ}, 37.0^{\circ} \mathrm{W}\right)$ to the Western Atlantic Ocean in Aracaju City (ADEMA, 1984). The estuary has an area of $33 \mathrm{~km}^{2}$ with an average depth of $3 \mathrm{~m}$ (Alcântara et al., 1979). Runoff varies from $560,000 \mathrm{~m}^{3}$ per day in the rainy season to $70,000 \mathrm{~m}^{3}$ per day in the dry season (Harleman, 1979).

Aracaju, the capital of Sergipe State, has more than 461,000 inhabitants, and of 116,689 residences only $56.4 \%$ are linked to the official system of domestic sewage treatment (IBGE, 2000). Industries that discharge waste directly into the river include sugar and paper mills, textile industries, beverage manufacture and coconut processing (JICA, 1998). Formerly, mangrove forests covered the estuarine margins, but large areas have been logged to accommodate urban expansion since 1975 (JICA, 1998; Souza, 2000).

\subsection{Sampling and sample processing}

Sampling was conducted every three hours over a 24 hours period at a station $3 \mathrm{~km}$ from the Sergipe River inlet (Figure 1). Sampling was performed from 28 to 29 July 2001 (rainy season) and from 07 to 08 February 2002 (dry season). Both sampling periods corresponded to neap tide, with an average amplitude of approximately $1.0 \mathrm{~m}$.

Water samples were taken with a Van Dorn bottle at subsurface and near the bottom (local depth $3 \mathrm{~m}$ ). The following variables were measured: temperature (digital thermometer, $0.5{ }^{\circ} \mathrm{C}$ accuracy), salinity (refractometer, American Optical, Model 10423), pH (portable pH meter), and dissolved oxygen (Winkler method, Strickland and Parsons 1965). Water samples for measurements of chlorophyll- $a$ were immediately transferred to the adjacent laboratory, and filtered through a $0.45 \mu \mathrm{m}$ Millipore filter. Chlorophyll- $a$ was measured on a Femto 700 Plus spectrophotometer by the tri-chromatic method (Strickland and Parsons 1965) and nutrients (ammonia, nitrite, nitrate and phosphate) according to APHA (1995). The molecular ratio of total inorganic nitrogen (TIN), i.e. the sum of $\mathrm{NO}_{3}^{-}+\mathrm{NO}_{2}^{-}+\mathrm{NH}_{4}^{+}$, to $\mathrm{PO}_{4}^{-}$was calculated to assess the limiting nutrient.

The micro- and mesozooplankton were sampled with two different plankton nets (mesh sizes 75 and $200 \mu \mathrm{m}$, mouths diameter $0.3 \mathrm{~m}$ ) towed simultaneously for 3 minutes at sub-surface. A calibrated flowmeter (General Oceanics model 2030) was fitted on the opening of each net. Samples were preserved in a $4 \%$ buffered formaldehyde seawater solution. All zooplankters were identified as accurately as possible, mostly to species or 

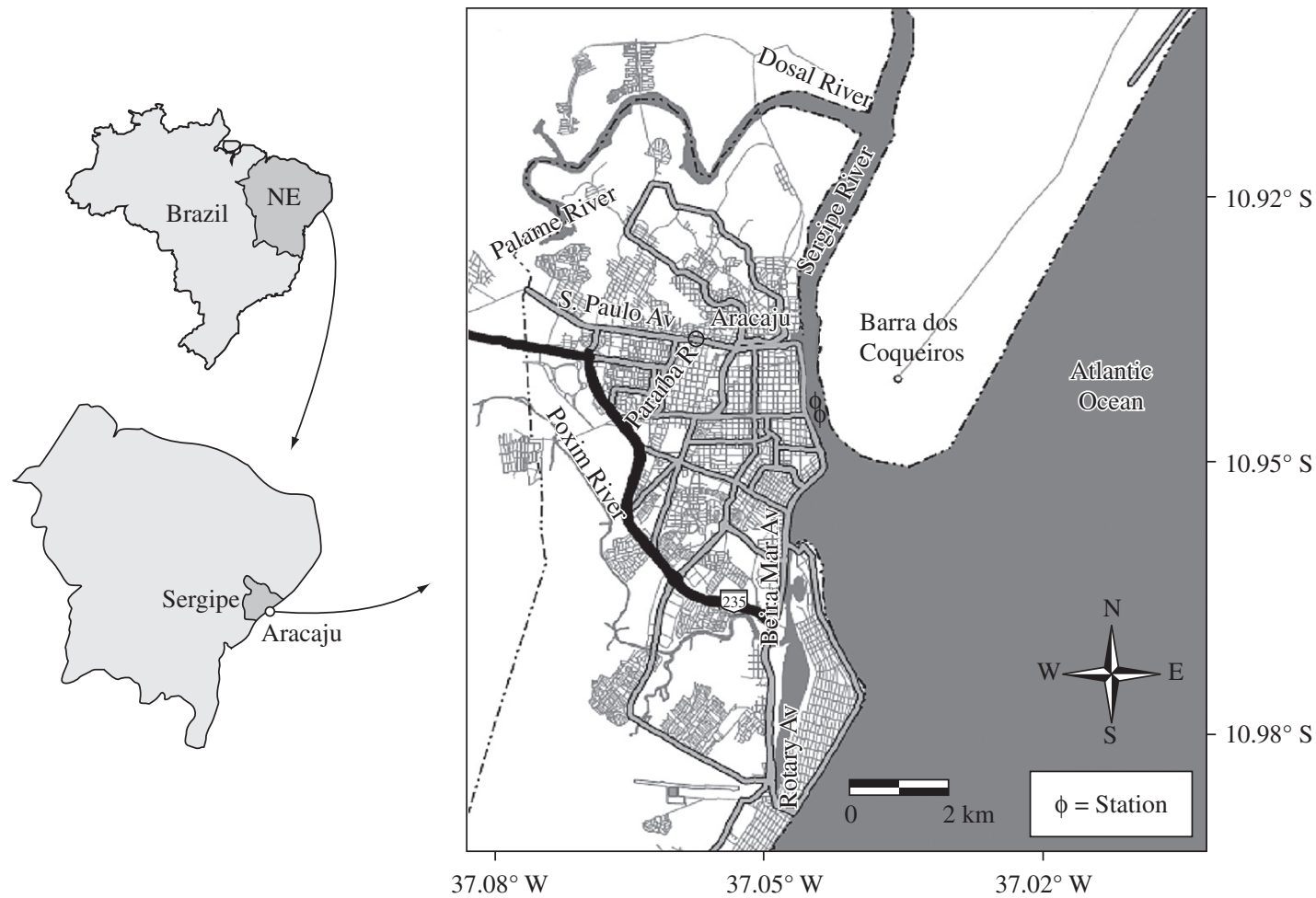

Figure 1. Map of the Sergipe River estuary (Northeastern Brazil) and the position of the sampling station.

genus level. After the sample was diluted to $500 \mathrm{~mL}$ and gently homogenized, abundance was estimated under a stereomicroscope on the basis of $2 \mathrm{~mL}$ subsamples taken with a Stempel-pipette. Three subsamples were counted and the average value was calculated.

\subsection{Data analysis}

To verify potential correlations between abiotic and biotic variables, Spearman rank correlation analysis (Zar, 1990) was performed at $\alpha=0.05$ with the 20 main parameters (concentrations of nutrients, oxygen and chlorophyll- $a$, and densities of the most abundant microand mesozooplankton taxa). One-way Kruskal-Wallis ANOVA (Zar, 1990) was used to test for significant $(\alpha=0.05)$ effects of the factors "depth", "season", "day/ night", and "tide" on the same 20 main abiotic and biotic parameters. These analyses were performed with STATISTICA 5.1 (StatSoft Inc.).

The Shannon diversity index (H') was applied for the estimation of community diversity based on $\log _{2}$ (Shannon, 1948). Evenness was calculated according to Pielou (1967). Cluster analysis on the sample-species data matrix used the Bray-Curtis index and the Ward cluster method. Relations between biotic and abiotic data were analyzed through canonical correspondence analysis (Ter Braak, 1986). Multivariate analysis was performed with the most important species only (more than $0.3 \%$ of the total abundance), using the CANOCO 3.1 software (Ter Braak, 1989; Ter Braak and Smilauer, 1998).

\section{Results}

\subsection{Abiotic factors}

Temperatures in July (average: surface $25 \pm 1.13{ }^{\circ} \mathrm{C}$; bottom $24.63 \pm 0.44$ ) were generally lower than in February (average: surface $27.38 \pm 0.88{ }^{\circ} \mathrm{C}$; bottom $27.19 \pm 0.96)$. No thermal stratification was observed. The $\mathrm{pH}$ was above 8 in all water samples (Table 1).

Salinity ranged from 21.4 to 32.6 in July, and from 23.9 to 32.6 in February, the wider range being during the rainy season. The salinity regime was euhaline-polyhaline with a strong marine influence.

In July, average dissolved oxygen concentrations were $7.67 \pm 0.49 \mathrm{mg} . \mathrm{L}^{-1}$ at the surface and $6.95 \pm 0.38 \mathrm{mg} . \mathrm{L}^{-1}$ at the bottom. In February, average values were $6.53 \pm 0.35 \mathrm{mg} . \mathrm{L}^{-1}$ at the surface and $6.28 \pm 0.24 \mathrm{mgL}^{-1}$ at the bottom. Oxygen saturation was always close to $100 \%$.

Nutrient concentrations $\left(\mathrm{NH}_{4}, \mathrm{NO}_{2}, \mathrm{NO}_{3}\right.$, and $\left.\mathrm{PO}_{4}\right)$ had considerable variation according to tidal situation and season (Table 1). Phosphate and dissolved oxygen concentrations were higher in the rainy season, when a strong water flux from upstream diluted the urban sewage. Concentrations of nitrite, ammonia at the bottom and nitrate at the bottom were significantly higher during the dry season when the load of organic matter was high.

In July, average N:P ratio varied from 0.6 to 4.2 , this being lower than the Redfield ratio (7.3), and hence ni- 
Table 1. Environmental variables during the tidal cycle in July 2001 and February 2002.

\begin{tabular}{|c|c|c|c|c|c|c|c|c|}
\hline \multirow[t]{2}{*}{ Parameter } & \multicolumn{4}{|c|}{ July } & \multicolumn{4}{|c|}{ February } \\
\hline & Min & Max & Aver & SD & Min & Max & Aver & SD \\
\hline Chlorophyll- $a\left(\mu \mathrm{g} \cdot \mathrm{L}^{-1}\right)$ & 0.00 & 3.96 & 1.84 & 1.48 & 0.23 & 2.80 & 1.21 & 0.88 \\
\hline Temperature $(\mathrm{S})\left({ }^{\circ} \mathrm{C}\right)$ & 23.00 & 27.00 & 25.00 & 1.13 & 26.00 & 28.50 & 27.38 & 0.88 \\
\hline Temperature (B) $\left({ }^{\circ} \mathrm{C}\right)$ & 24.00 & 25.00 & 24.63 & 0.44 & 26.00 & 28.50 & 27.19 & 0.96 \\
\hline $\mathrm{pH}(\mathrm{S})$ & 8.00 & 8.20 & 8.10 & 0.05 & 8.00 & 8.20 & 8.09 & 0.08 \\
\hline $\mathrm{pH}(\mathrm{B})$ & 8.10 & 8.10 & 8.10 & 0.00 & 8.00 & 8.30 & 8.11 & 0.11 \\
\hline Salinity (S) & 21.40 & 29.20 & 24.80 & 2.65 & 23.90 & 31.50 & 27.00 & 2.57 \\
\hline Salinity (B) & 30.50 & 32.60 & 31.03 & 0.69 & 29.50 & 32.60 & 31.50 & 1.20 \\
\hline Dissolved Oxygen (S) (mg.L $\left.\mathrm{L}^{-1}\right)$ & 7.14 & 8.53 & 7.67 & 0.49 & 5.95 & 6.95 & 6.53 & 0.35 \\
\hline Dissolved Oxygen (B) (mg. $\left.\mathrm{L}^{-1}\right)$ & 6.38 & 7.53 & 6.95 & 0.38 & 5.88 & 6.61 & 6.28 & 0.24 \\
\hline Ammonia $(\mathrm{S})\left(\mu \mathrm{g} . \mathrm{L}^{-1}\right)$ & 5.42 & 39.29 & 14.41 & 11.84 & 8.94 & 21.88 & 13.95 & 4.01 \\
\hline Ammonia (B) $\left(\mu \mathrm{g} . \mathrm{L}^{-1}\right)$ & 4.14 & 13.89 & 6.98 & 3.12 & 7.18 & 16.45 & 12.93 & 2.95 \\
\hline Nitrite $(\mathrm{S})\left(\mu \mathrm{g} \cdot \mathrm{L}^{-1}\right)$ & 0.14 & 4.23 & 1.81 & 1.46 & 5.77 & 13.80 & 10.52 & 3.09 \\
\hline Nitrite (B) $\left(\mu \mathrm{g} \cdot \mathrm{L}^{-1}\right)$ & 0.14 & 5.46 & 1.30 & 1.80 & 4.84 & 11.64 & 8.20 & 2.56 \\
\hline Nitrate $(S)\left(\mu \mathrm{g} . \mathrm{L}^{-1}\right)$ & 3.55 & 101.10 & 33.31 & 41.47 & 35.74 & 55.96 & 44.52 & 6.65 \\
\hline Nitrate (B) $\left(\mu \mathrm{g} . \mathrm{L}^{-1}\right)$ & 4.12 & 60.08 & 18.58 & 19.96 & 37.21 & 61.84 & 47.14 & 7.75 \\
\hline Phosphate (S) $\left(\mu \mathrm{g} \cdot \mathrm{L}^{-1}\right)$ & 12.05 & 21.04 & 16.87 & 3.93 & 0.91 & 9.48 & 2.41 & 3.10 \\
\hline Phosphate (B) $\left(\mu \mathrm{g} . \mathrm{L}^{-1}\right)$ & 13.33 & 26.17 & 20.07 & 4.54 & 0.91 & 10.77 & 2.57 & 3.52 \\
\hline
\end{tabular}

Min = minimum, Max = maximum, Aver $=$ average, $\mathrm{SD}=$ standard deviation, $\mathrm{S}=$ surface, $\mathrm{B}=$ bottom.

trogen was the limiting nutrient. In February, the average ratio varied from 11.6 to 26.7 , with phosphorus being the limiting factor.

Chlorophyll- $a$ concentrations were always low, with average values of $1.84 \pm 1.48 \mu \mathrm{g} . \mathrm{L}^{-1}$ in July and $1.21 \pm$ $0.88 \mu \mathrm{g} . \mathrm{L}^{-1}$ in February (Table 1).

\subsection{Species composition and density}

Fifty-nine micro- and mesozooplankton taxa were identified (Table 2). Generally, holoplanktonic organisms predominated $(81 \%)$ over the meroplankton $(19 \%)$. Nearly all zooplankton was composed of typical marine euryhaline species. The richest Class was Copepoda, with 23 species. The most common copepods were, in the microzooplankton samples, Parvocalanus crassirostris (copepodite), Oithona nana and O. hebes and, in the mesozooplankton samples, Parvocalanus crassirostris, Paracalanus quasimodo and Temora turbinata. There were high numbers of bivalve larvae in the $75 \mu \mathrm{m}$ samples and barnacle larvae in the $200 \mu \mathrm{m}$ samples. Gastropod and polychaete larvae were occasionally present in high numbers.

Microzooplankton diversity was very low, ranging from 0.35 bits.ind $^{-1}$ (July, diurnal ebb tide) to 1.61 bits.ind $^{-1}$ (February, nocturnal ebb tide) (Figure 2), with an average of $0.66 \pm 0.37$ bits.ind $^{-1}$ in July and $1.05 \pm 0.38$ bits.ind $^{-1}$ in February. This low diversity was clearly related to the general dominance of the tintinnid Favella ehrenbergii, which accounted for $69.8 \%$ and $78.5 \%$ of the microzooplankton assemblage.

Mesozooplankton diversity was generally low in July $\left(1.96 \pm 1.02\right.$ bits.ind $\left.^{-1}\right)$, although a single higher diversity

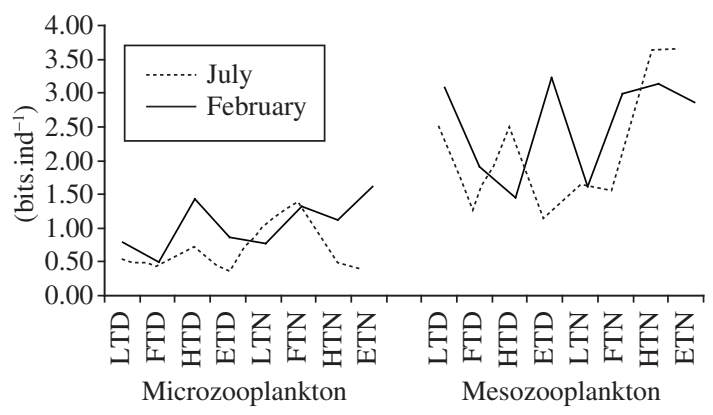

Figure 2. Zooplankton species diversity during the dry and rainy seasons. Low tide (LT), flood tide (FT), high tide (HT), ebb tide (ET), diurnal (D), nocturnal (N).

value of 3.66 bits.ind $^{-1}$ was registered at nocturnal high tide (Figure 2). In February (dry season), average diversity was higher $\left(2.96 \pm 0.74\right.$ bits.ind $\left.^{-1}\right)$, with a maximum of 3.20 bits.ind $^{-1}$ at diurnal flood tide (Figure 2).

Total zooplankton average density during the dry and rainy season presented significant differences (KruskalWallis $\mathrm{p}<0.05$ ), mainly in the microzooplankton fraction. In July, microzooplankton average density was $86,002 \pm 59,074$ ind. $\mathrm{m}^{-3}$, ranging from 18,649 ind. $\mathrm{m}^{-3}$ (nocturnal high tide) to 168,962 ind. $\mathrm{m}^{-3}$ (diurnal ebb tide) (Figure 3). The holoplankton dominated with $71.9 \%$, with $69.8 \%$ being $F$. ehrenbergii; the density of this species (Figure 4) varied from 17,603 to 162,477 ind. $\mathrm{m}^{-3}$. The meroplankton accounted for $28.1 \%$ of the microzooplankton, with $26.7 \%$ being Bivalvia larvae. In February 
Table 2. Micro and mesozooplankton composition in the Sergipe River estuary in northeastern Brazil, during the rainy (July 2001) and dry (February 2002) seasons.

\begin{tabular}{|c|c|}
\hline \multicolumn{2}{|c|}{ Taxa } \\
\hline Foraminiferida & Oithona plumifera Baird, 1843 \\
\hline Tintinnina & Oithona simplex Farran, 1913 \\
\hline Favella ehrenbergii (Claparède and Laachmann, 1858) & Oithona hebes Giesbrecht, 1891 \\
\hline Leprotintinnus nordqvisti (Brandt, 1906) & Oithona spp. \\
\hline Hydrozoa & Euterpina acutifrons (Dana, 1852) \\
\hline Bougainvillia ramosa (Van Beneden, 1844) & Oncaea media Giesbrecht, 1891 \\
\hline Eucheilota duodecimales A. Agassiz, 1862 & Corycaeus amazonicus F. Dahl, 1849 \\
\hline Eutima sp. & Corycaeus giesbrecht F. Dahl, 1849 \\
\hline Liriope tetraphylla (Chamisso and Eysenhardt, 1821) & Corycaeus spp. \\
\hline Siphonophorae & Hemicyclops thalassius (Vervoort and Ramírez,1966) \\
\hline Scyphozoa - Scyphomedusae & Copepoda (nauplius) \\
\hline Polychaeta (larvae) & Cirripedia (nauplius and cypris) \\
\hline Cladocera & Decapoda (larvae) \\
\hline Penilia avirostris Dana, 1852 & Lucifer faxoni Borradaile, 1915 \\
\hline Ostracoda & Amphipoda \\
\hline Copepoda & Isopoda (larvae) \\
\hline Paracalanus aculeatus Giesbrecht, 1888 & Gastropoda (larvae) \\
\hline Paracalanus quasimodo Bowman, 1971 & Bivalvia (larvae) \\
\hline Paracalanus spp. (copepodite) & Ectoprocta (Membranipora sp. larvae) \\
\hline Parvocalanus crassirostris F. Dahl,1894 & Echinodermata (Echinopluteus) \\
\hline Subeucalanus pileatus Giesbrecht, 1888 & Echinodermata (Ophiopluteus) \\
\hline Centropages furcatus (Dana, 1849) & Chaetognatha \\
\hline Pseudodiaptomus acutus (F. Dahl, 1894) & Sagitta enflata Grassi, 1881 \\
\hline Pseudodiaptomus richardi F. Dahl, 1894 & Sagitta tenuis Conant, 1896 \\
\hline Temora stylifera Dana, 1848 & Appendicularia \\
\hline Temora turbinata (Dana, 1849) & Oikopleura dioica Fol,1872 \\
\hline Calanopia americana F. Dahl, 1894 & Oikopleura longicauda (Vogt, 1854) \\
\hline Labidocera fluviatilis F. Dahl, 1894 & Thaliacea \\
\hline Pontellopsis brevis (Giesbrecht, 1889) & Thalia democratica (Forskal, 1775) \\
\hline Acartia lilljeborgi Giesbrecht, 1889 & Doliolum sp. \\
\hline Oithona nana Giesbrecht, 1892 & Teleostei (egg and larvae) \\
\hline
\end{tabular}

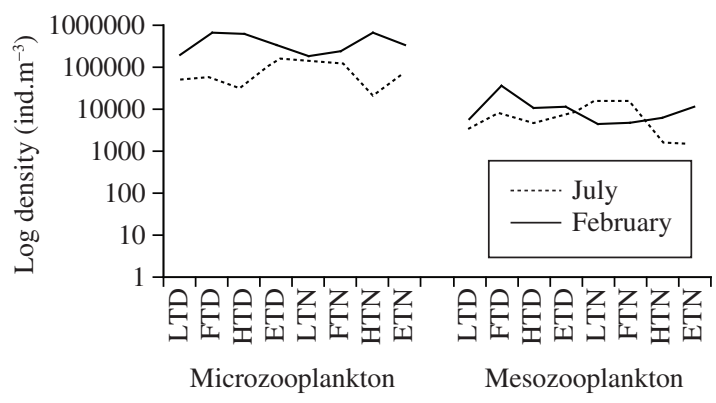

Figure 3. Zooplankton total density during the dry and rainy seasons. Low tide (LT), flood tide (FT), high tide (HT), ebb tide (ET), diurnal (D), nocturnal (N).

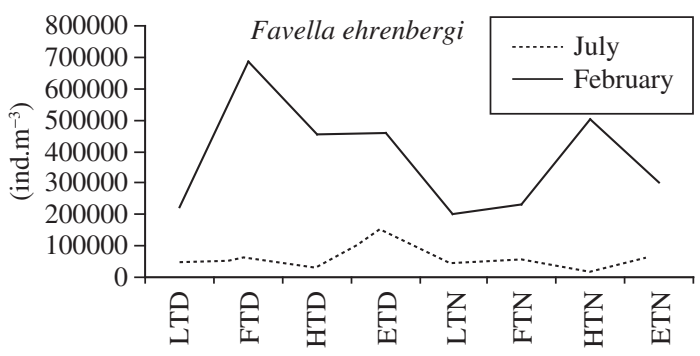

Figure 4. Density of Favella ehrenbergii sampled with a $75 \mu \mathrm{m}$ mesh net during the dry and rainy seasons. Low tide (LT), flood tide (FT), high tide (HT), ebb tide (ET), diurnal (D), nocturnal (N). 
the average density was 410,232.9 $\pm 59,074$ ind. $\mathrm{m}^{-3}$, with a minimum of 182,622 ind. $\mathrm{m}^{-3}$ at diurnal low tide and a maximum of 678,009 ind. $\mathrm{m}^{-3}$ at nocturnal high tide (Figure 3). The holoplankton accounted for $85.0 \%$ of the relative abundance, with $78.6 \%$ being Favella ehrenbergii; the density of this species varied from 158,118 to 626,147 ind.m ${ }^{-3}$ (Figure 4 ). The meroplankton accounted for $15.0 \%$ of the relative abundance, with $14.3 \%$ being Bivalvia larvae.

The mesozooplankton average density in July was 7,519 $\pm 6,064$ ind. $\mathrm{m}^{-3}$ and varied between 1,537 at nocturnal ebb tide to 16,580 ind. $\mathrm{m}^{-3}$ at nocturnal flood tide (Figure 3). The meroplankton accounted for $87.9 \%$ : 72.7\% Cirripedia nauplii, $7.9 \%$ Decapoda larvae and $2.2 \%$ Bivalvia larvae. The holoplankton comprised $12.1 \%$, with $7.0 \%$ being Copepoda, and $2.4 \%$ being specifically Acartia lilljeborgii.

In February, the average density was $11,566 \pm 10,750$ ind. $\mathrm{m}^{-3}$, varying from 4,405 ind. $\mathrm{m}^{-3}$ at dusk low tide to 37,062 ind. $\mathrm{m}^{-3}$ at diurnal flood tide (Figure 3). The holoplankton comprised $84.7 \%$ of the community, with $43.0 \%$ being Copepoda and $39.1 \%$ Favella ehrenbergi. The most abundant Copepoda were Parvocalanus crassirostris (22.9\% of the holoplankton), Paracalanus quasimodo (6.39\%) and Temora turbinata $(5.45 \%)$. The meroplankton comprised $15.3 \%$, with $8.6 \%$ being Cirripedia larvae.

\subsection{Community analysis}

Spearman correlation analysis with an input matrix of $42 \times 42$ variables yielded 126 significant correlations (65 positive and 59 negative, not shown). However, there was no correlation (positive or negative) between chlorophyll- $a$ concentration and any other parameter, including nutrient concentrations.

Kruskal-Wallis ANOVA showed that among the four factors considered, only the factor "season" showed significant differences (Table 3). Temperature was significantly higher during the dry season, as expected for the region. Oxygen and phosphate concentrations were significantly higher in the rainy season, whereas nitrite concentrations were significantly higher in the dry season. Total microzooplankton density, and the densities of F. ehrenbergii (in micro- and mesozooplankton samples), Oithona hebes, O. nana, and Euterpina acutifrons (in the mesozooplankton) were significantly higher in the dry season, whereas microzooplankton diversity and densities of $O$. plumifera, Acartia lilljeborgi, and fish eggs were significantly higher in the rainy season (Table 3).

Cluster analysis by samples clearly showed that the two plankton nets sampled different communities. Each group could be divided into February and July to reflect significant $(\mathrm{p}<0.05)$ differences (Figure 5). Liriope tetraphylla, Eutima sp., Pontellopsis brevis, Sagitta enflata and Thalia democratica occurred only in July (rainy season), whereas Bougainvillia ramosa, Eucheillota duodecimalis, Paracalanus aculeatus,
Table 3. One-way Kruskal-Wallis ANOVA results conducted with 42 parameters and four factors ("season", depth", "day/night", and "tide). Only the factor "season" showed significant differences. D: dry season, R: rainy season.

\begin{tabular}{lc}
\hline \multicolumn{1}{c}{ Parameter } & Seasonal effect $(\mathbf{p})$ \\
\hline Temperature & $0.0019(\mathrm{D}>\mathrm{R})$ \\
Oxygen concentration & $0.0008(\mathrm{R}>\mathrm{D})$ \\
Oxygen saturation & $0.016(\mathrm{R}>\mathrm{D})$ \\
Phosphate & $0.0005(\mathrm{R}>\mathrm{D})$ \\
Nitrite & $0.0008(\mathrm{D}>\mathrm{R})$ \\
Microzooplankton $\mathbf{( 7 5} \mu \mathbf{m})$ & \\
Favella ehrenbergii & $0.0011(\mathrm{D}>\mathrm{R})$ \\
Oithona plumifera & $0.033(\mathrm{R}>\mathrm{D})$ \\
Total microzooplankton & $0.0008(\mathrm{D}>\mathrm{R})$ \\
Diversity & $0.036(\mathrm{R}>\mathrm{D})$ \\
Mesozooplankton $(\mathbf{2 0 0} \mu \mathbf{m})$ & \\
Favella ehrenbergii & $0.02(\mathrm{D}>\mathrm{R})$ \\
Acartia lilljeborgi & $0.0205(\mathrm{R}>\mathrm{D})$ \\
Oithona hebes & $0.0016(\mathrm{D}>\mathrm{R})$ \\
Oithona nana & $0.005(\mathrm{D}>\mathrm{R})$ \\
Euterpina acutifrons & $0.0237(\mathrm{D}>\mathrm{R})$ \\
Fish eggs & $0.0022(\mathrm{R}>\mathrm{D})$ \\
\hline
\end{tabular}

Pseudodiaptomus richardi, Oithona plumifera, Oithona simplex, Oncaea media and Farranula gracilis were registered only in February (dry season).

Cluster analysis by taxa showed the existence of three groups (Figure 6): resilient estuarine species that occurred in both seasons; species that were more abundant mainly in July, when an intense flux of unpolluted water from upstream diluted the urban sewage, allowing the survival of Decapoda and fish larvae; and marine zooplankton that occurred in large numbers mainly in February, brought into the area by the marine influx.

Canonical correspondence analysis revealed the correlation of the microzooplankton community with the bottom phosphate and surface salinity $(\mathrm{p}<0.05)$. The environmental variables measured and included in the analysis explained $60.7 \%$ of the variation in biotic data. There is a seasonal variation, with July samples on the right side of the plot and February samples on the left side (Figure 7). Phosphate and dissolved oxygen were higher in July when the urban sewage was diluted by upstream fluxes.

In February, during the dry season when the residence time of the domestic sewage was higher, the high organic matter increased the nitrite, nitrate and ammonia. Salinity and temperature were also higher. In these conditions Favella ehrenbergii (average density 322,235 ind. $\mathrm{m}^{-3}$ ) and Bivalvia larvae (average density 58,599 ind. $\mathrm{m}^{-3}$ ) were the dominant taxa and together reached $92.8 \%$ of the microzooplankton assemblage. Parvocalanus crassirostris, Oithona nana, O. hebes, Calanopia americana, Euterpina acutifrons, 


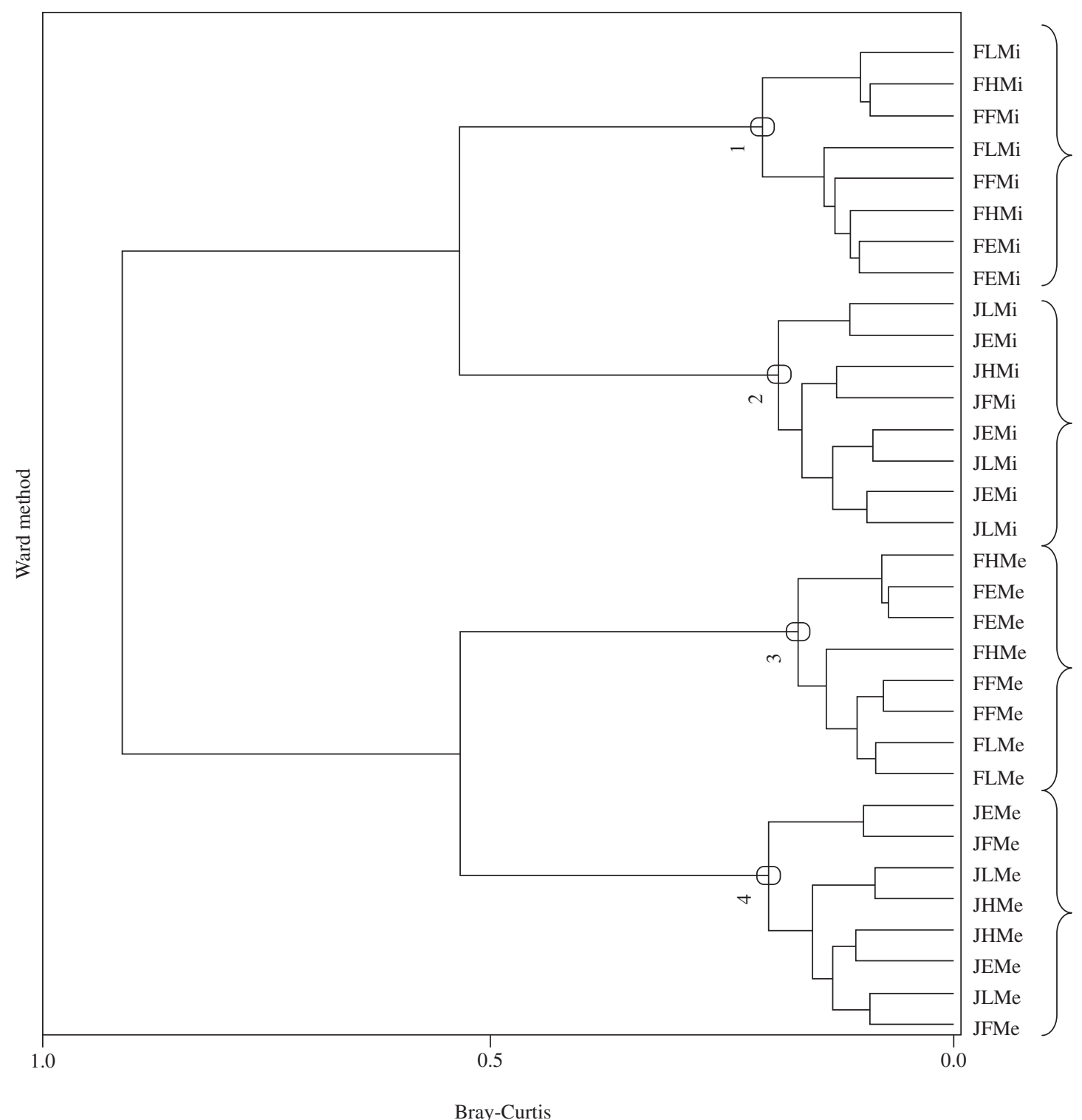

Figure 5. Cluster analysis (Q mode analysis) of samples from the Sergipe River estuary in July 2001 (J) and February 2002 (F). Second symbol: L, low tide; F, flood tide; H, high tide; E, ebb. Two final letters: Mi, microzooplankton; Me, mesozooplankton.

Temora stylifera and T. turbinata were more abundant in February when tide currents and salinity were higher.

Canonical correspondence analysis showed that the mesozooplankton were significantly correlated with the nitrite, ammonia and dissolved oxygen $(\mathrm{p}<0.05)$. The biplot of stations and environmental variables (Figure 8) is similar to that for microzooplankton, with a clear seasonal pattern where July samples are on the right side of the plot and February samples on the left side.

The measured environmental variables explained $63.2 \%$ of the variation in biotic data. In July, Cirripedia nauplii (average density 5,466 ind. $\mathrm{m}^{-3}$ ) were domi- nant $(72.7 \%)$, and larvae of Decapoda, Bivalvia and Echinodermata were also important. In February, F. ehrenbergii accounted for $39.1 \%$ of the individuals caught in the mesozooplankton net despite its small size.

\section{Discussion}

This study examined the seasonal and tidal variation of micro- and mesozooplankton in the Sergipe River estuary aiming a more comprehensive understanding of the biodiversity and species abundance, and their relation to physico-chemical conditions. Little is known about the 


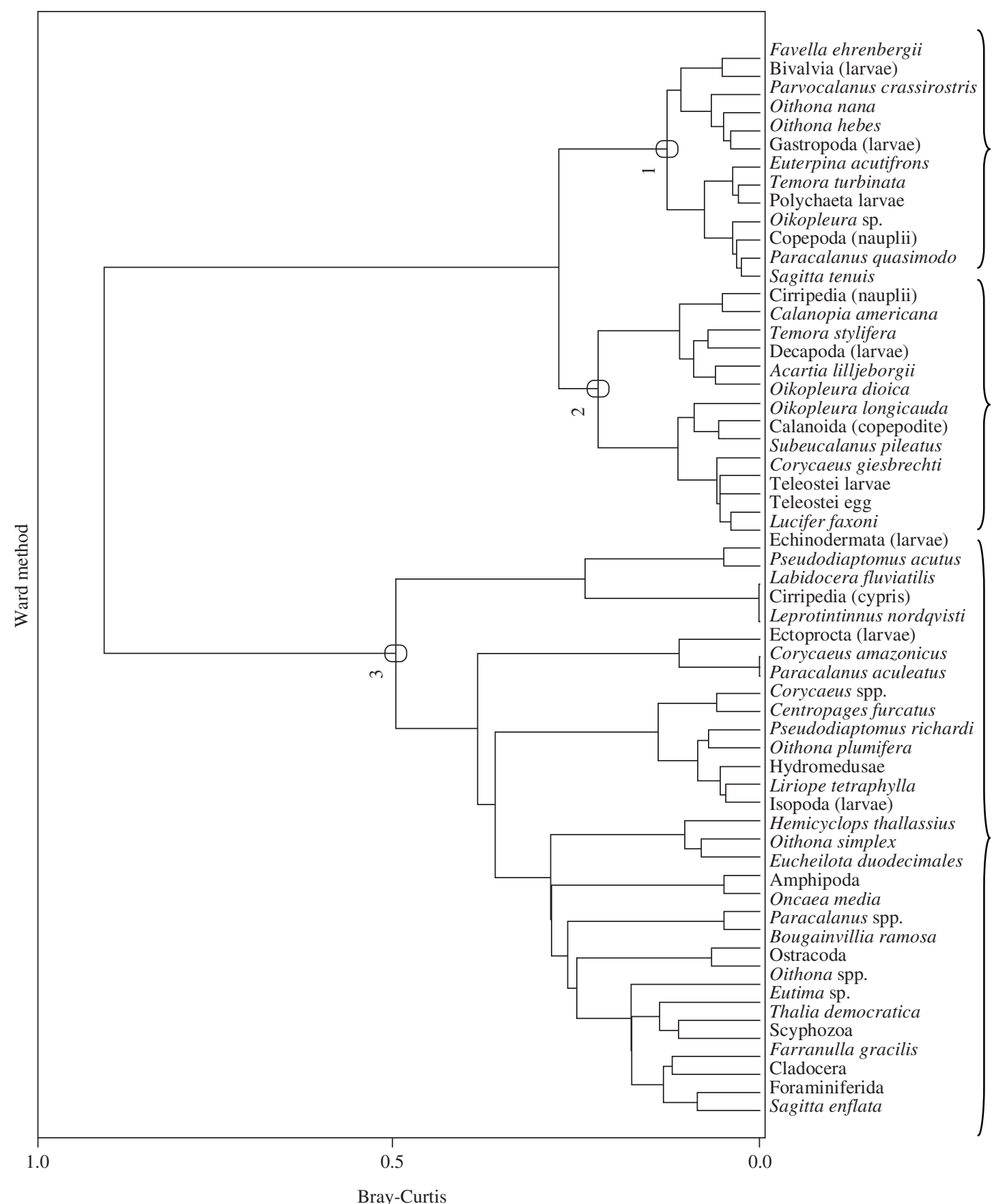

Figure 6. Cluster analysis (R mode analysis) results on the basis of zooplankton composition in the Sergipe River estuary in July 2001 and February 2002.

zooplankton dynamics in tropical estuaries. According to Buskey (1993), micro- and mesozooplankton have rarely been studied concurrently in tropical or temperate estuaries.

Tropical and subtropical estuaries fundamentally differ from the more commonly studied temperate estuaries, in that they experience less marked seasonal changes in temperature and solar radiation. During this study, the temperature averaged between 24 and $27^{\circ} \mathrm{C}$. In most tropical and sub-tropical estuaries, where temperature and solar radiation are higher than in temperate zones, turnover rates are also high and in many countries, there is often little or no treatment of domestic sewage (Lam and Ho, 1989). Thus, extreme eutrophication is common in 


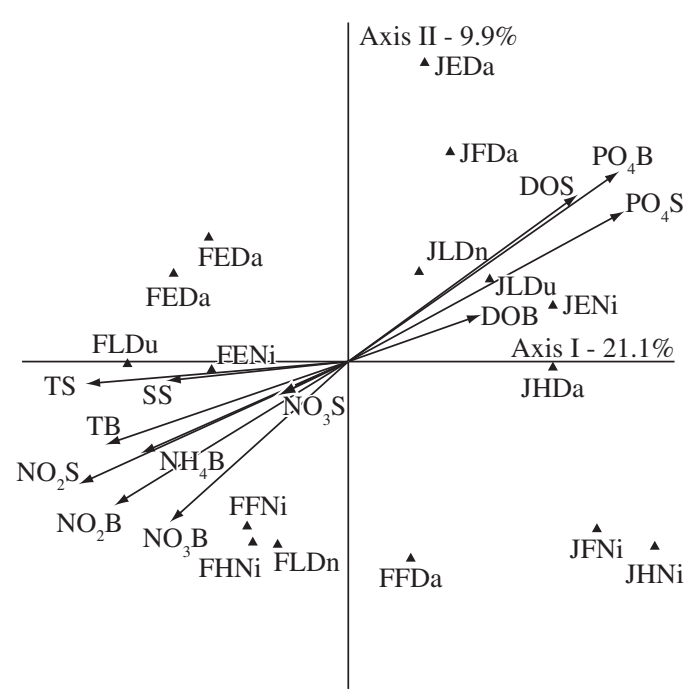

Figure 7. Correlations of microzooplankton with environmental variable vectors and samples in the Sergipe River estuary in July 2001 (J) and February 2002 (F); Axis 1 and 2 biplot showing results of CCA analysis. Tide stages: flood tide $(\mathrm{F})$, high tide $(\mathrm{H})$, ebb tide $(\mathrm{E})$, low tide $(\mathrm{L})$. Periods of the day: dawn (Dn), day (Da), dusk (Du) and night (Ni). Abiotic data: Temperature Surface (TS), Temperature Bottom (TB), Salinity Surface (SS), Salinity Bottom (SB), Dissolved Oxygen Surface (DOS), Dissolved Oxygen Bottom (DOB), Ammonia Surface $\left(\mathrm{NH}_{4} \mathrm{~S}\right)$, Ammonia Bottom $\left(\mathrm{NH}_{4} \mathrm{~B}\right)$, Nitrite Surface $\left(\mathrm{NO}_{2} \mathrm{~S}\right)$, Nitrite Bottom $\left(\mathrm{NO}_{2} \mathrm{~B}\right)$, Nitrate Surface $\left(\mathrm{NO}_{3} \mathrm{~S}\right)$, Nitrate Bottom $\left(\mathrm{NO}_{3} \mathrm{~B}\right)$, Phosphate Surface $\left(\mathrm{PO}_{4} \mathrm{~S}\right)$, Phosphate Bottom $\left(\mathrm{PO}_{4} \mathrm{~B}\right)$.

coastal and estuarine areas. Our results showed that the Sergipe River estuary receives large amounts of nutrients. This is a consequence of the increasing growth of human populations in the Sergipe River watershed, combined with the spread of industrial and agricultural technologies. Most of the problems observed in this estuary are related to domestic sewage, thus closely linked to human population density. This is a feature common to most estuaries in northeastern Brazil, mainly those close to cities (Sankarankuty et al., 1979; Neumann-Leitão et al., 1992; 1996; Neumann-Leitão and Matsumura-Tundisi, 1998; Silva et al., 2003).

Relatively high loads of nutrients in both months caused by anthropogenic inputs could favor phytoplankton growth, but the turbidity of the water (transparency $<0.20 \mathrm{~m}$ ) probably limited the primary production. Restricted phytoplankton biomass in estuaries as a result of light limitation is a feature commonly found in northeastern Brazil (Eskinazi-Leça et al., 2000), and there is an increasing trend towards light limitation as continuous deforestation of mangrove and riparian vegetation causes higher loads of suspended matter.

In July, primary productivity was limited by nitrogen, whereas in February phosphorus was the limiting nutrient. Input of organic nitrogen matter from anthropogenic sources associated with transformation and mobilization

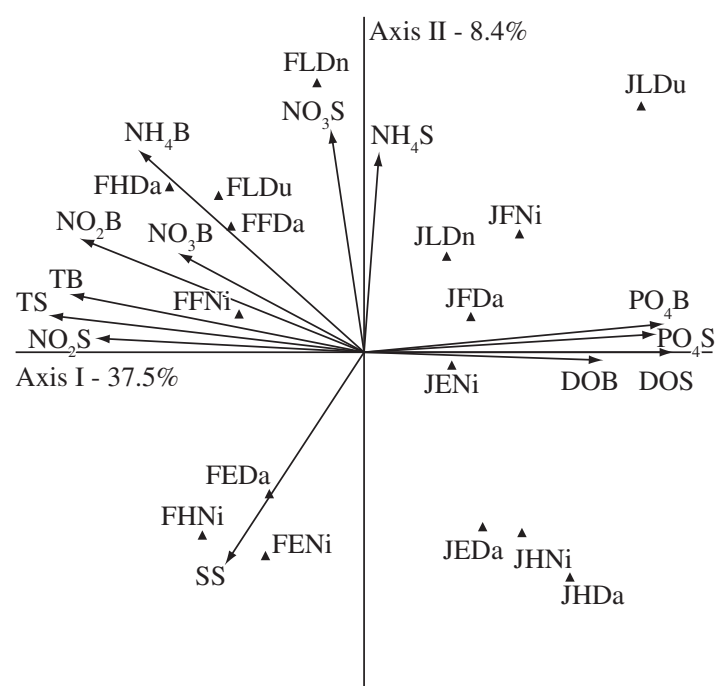

Figure 8. Correlations of mesozooplankton with environmental variable vectors and samples in the Sergipe River estuary in July 2001 (J) and February 2002 (F); Axis 1 and 2 biplot showing results of CCA analysis. Tide stages: flood tide $(\mathrm{F})$, high tide $(\mathrm{H})$, ebb tide $(\mathrm{E})$, low tide $(\mathrm{L})$. Periods of the day: dawn (Dn), day (Da), dusk (Du) and night (Ni). Abiotic data: Temperature Surface (TS), Temperature Bottom (TB), Salinity Surface (SS), Salinity Bottom (SB), Dissolved Oxygen Surface (DOS), Dissolved Oxygen Bottom (DOB), Ammonia Surface $\left(\mathrm{NH}_{4} \mathrm{~S}\right)$, Ammonia Bottom $\left(\mathrm{NH}_{4} \mathrm{~B}\right)$, Nitrite Surface $\left(\mathrm{NO}_{2} \mathrm{~S}\right)$, Nitrite Bottom $\left(\mathrm{NO}_{2} \mathrm{~B}\right)$, Nitrate Surface $\left(\mathrm{NO}_{3} \mathrm{~S}\right)$, Nitrate Bottom $\left(\mathrm{NO}_{3} \mathrm{~B}\right)$, Phosphate Surface $\left(\mathrm{PO}_{4} \mathrm{~S}\right)$, Phosphate Bottom $\left(\mathrm{PO}_{4} \mathrm{~B}\right)$.

of $\mathrm{N}$ and $\mathrm{P}$ at the water-sediment interface can change the N limitation to P (Paerl, 1997). This probably occurred in February, when there was little dilution of domestic sewage in the river because rainfall was low. An increase in microzooplankton abundance was observed during the dry season, when the concentration of nitrogen was higher. In experimental studies carried out by Gismervik et al. (2002), both micro- and mesozooplankton responded positively to increased nutrient loading; although the response of ciliates was rapid and shortlived, the mesozooplankton had doubled in biomass.

In the present study, microzooplankton density exceeded five times the mesozooplankton density, mainly due to presence of the tintinnid F. ehrenbergii. Tintinnids are an important component of the planktonic microprotozoan community in most marine environments (Landry and Hasset, 1982; Verity, 1987; Pierce and Turner, 1993; Cordeiro et al., 1997; Tillmann, 2004), and they can be important occasionally in estuarine waters (Sanders, 1987; Barría de Cao, 1992; Dolan and Gallegos, 2001; Urrutxurtu, 2004). In the São Sebastião Channel (São Paulo) under estuarine influence, tintinnids represented the most abundant group of the microzooplankton community (Eskinazi-Sant'Anna and Björnberg, 2006).

High abundance, fast reproduction rates, and short generation times, coupled with a high capacity to use a 
large spectrum of food resources, enhance the importance of tintinnids as a key trophic link between the microbial and the metazoan compartments (Fenchel, 1980; Capriulo and Carpenter, 1983; Dolan and Marrasé, 1995; Capriulo et al., 2002; Urrutxurtu, 2004).

Some species have an apparent cosmopolitan distribution in the seas and oceans (Marshall, 1969). Favella ehrenbergii has been commonly found in coastal and estuarine areas in Brazil, in a high density in some periods (Neumann-Leitão et al., 1992; Lopes, 1994; EskinaziSant'Anna and Tundisi, 1996).

The high densities of $F$. ehrenbergii markedly influenced the structure of the microzooplankton community (negative contribution to Shannon's diversity index) in the present study. The diet of F. ehrenbergii is composed mainly of nanoflagellates (Bernard and Rassoulzadegan, 1993), and the species occurs in regions with high temperatures and highly variable salinity (Godhantaraman and Uye, 2003).

The mesozooplankton was dominated by copepods in February and by barnacle nauplii in July. This finding contradicts our original expectation that copepods and/ or decapod larvae would dominate in both zooplankton fractions in both periods, as has been commonly described for Brazilian tropical estuaries (Tundisi, 1970; Lopes et al., 1986; Lopes, 1994; Neumann-Leitão, 1995; Silva et al., 2004). The high abundance of barnacle larvae reflects the reproductive patterns of the benthic adult forms of these organisms, and shows their resilience in an impacted system. Barnacle nauplii were also the dominant group in the Ipojuca estuary in Pernambuco State, northeastern Brazil, a strongly polluted estuary (Neumann-Leitão and Matsumura-Tundisi, 1998).

Among the copepods in the Sergipe River estuary, Acartia lilljeborgi and Parvocalanus crassirostris were abundant. Acartia lilljeborgi had an important role in July (rainy season), and this may have been related to the large quantities of detritus occurring in this season; detritus can be consumed by this species (Schwamborn, 1997; Schwamborn et al., 1999). Parvocalanus crassirostris was important in July and it is very common in most Brazilian estuaries (Matsumura-Tundisi, 1972; Björnberg, 1981), even those that are heavily impacted (Schwamborn et al., 2004; Silva et al., 2004). Parvocalanus crassirostris feeds significantly on picoplankton and nanoplankton and behaves as an opportunistic particle feeder, showing higher consumption rates upon the most abundant cells (2-5 $\mu \mathrm{m}$ nanoplankton) (Calbet et al., 2000). Generally, it is an abundant species in eutrophic systems, showing its r-strategist behavior.

Other copepod species did not occur in any considerable number, most of them being typical of coastal waters (Boltovskoy, 1981; 1999; Neumann-Leitão et al., 1999; Magalhães et al., 2006) or euryhaline; this shows that the intense marine influx in the Sergipe River estuary during high tide altered the zooplankton composition.

In general, species distributions along the tidal cycle reflected an overlap of different patterns of marine and estuarine species. A more important intrusion of marine species (mainly copepods) in low densities was observed, which increased diversity in the mesozooplankton.

As a whole, the Sergipe River estuary is under environmental stress and it seems reasonable to assume that anthropogenic impacts in the watershed have resulted in changes in the species dynamics and trophic structure. During high tide, a very low density of a marine assemblage (e.g. Paracalanus quasimodo, P. indicus, Calanopia americana, Oncaea media, Corycaeus $(C$.) speciosus and Microsetella rosea) occasionally increases the species diversity and evenness.

\section{References}

ADEMA, 1984. Levantamento da flora e caracterização dos bosques de mangue do estado de Sergipe. Aracaju: ADEMA. 208 p. Technical report.

ALCÂNTARA, AV., ROCHA, CEF. and SANTOS, MA., 1979. Caracterização hidrológica e biológica do estuário do Rio Sergipe. Aracaju: ITPS/UFS/CNPq. 151 p. Technical report.

APHA - American Public Health Association, 1995. Standard methods for the examination of water and wastewater. 19 ed. Washington, DC.

ARAUJO, HMP., 1982. "Standing-stock" do zooplâncton do estuário do Rio Sergipe. Rev. Nordest. Biol., vol. 1, no. 5, p. 5-14.

BARRIA DE CAO, MS., 1992. Abundance and species composition of Tintinnina (Ciliophora) in Bahia Blanca Estuary, Argentina. Est. Coast. Shelf Sci., vol. 34, no. 3, p. 295-303.

BERNARD, C. and RASSOULZADEGAN, F., 1993. The role of picoplankton (cyanobacteria and plastidic picoflagellates) in the diet of tintinnids. J. Plankton Res., vol. 15, no. 4, p. 361-373.

BJÖRNBERG, TS., 1981. Copepoda. In BOLTOVSKOY, D. (Ed.). Atlas del zooplancton del Atlántico sudoccidental y métodos de trabajo con el zooplancton marino. Mar del Plata: INIDEP. p. 587-679.

BOLTOVSKOY, D., 1999. South Atlantic Zooplankton. Leiden: Backhuys Publishers. 1627 p.

BUSKEY, EJ., 1993. Annual pattern of micro- and mesozooplankton and biomass in a subtropical estuary. $J$. Plankton Res., vol. 15, no. 8, p. 907-924.

CALBET, A., LANDRY, MR. and SCHEINBERG, RD., 2000. Copepod grazing in a subtropical bay: species-specific responses to a midsummer increase in nanoplankton standing stock. Mar. Ecol. Prog. Ser., vol. 193, p. 75-84

CAPRIULO, GM. and CARPENTER, EJ., 1983. Abundance, species composition and feeding impact of tintinnid microzooplankton in Central Long Island Sound. Mar. Ecol. Prog. Ser., vol. 10, p. 277-288.

CAPRIULO, GM., SMITH, G., TROY, R., WIKFORS, GH., PELLET, J. and YARISH, C., 2002. The planktonic food web structure of a temperate zone estuary, and its alteration due to eutrophication. Hydrobiol., vol. 475/476, no. 1, p. 263-333.

CORDEIRO, TA., BRANDINI, FP. and MARTENS, P., 1997. Spatial distribution of the Tintinnina (Ciliophora, Protista) in 
the North Sea, spring of 1986. J. Plankton Res., vol. 19, no. 10, p. 1371-1383.

DAUVIN, JC., THIÉBAUT, E. and WANG, Z.,1998. Short-term changes in the mesozooplankton community in the Seine ROFI (Region of Freshwater Influence) (eastern English Channel). $J$. Plankton Res., vol. 20, no. 6, p. 1145-1167.

DAY JR., JW., HALL, CAJ., KEMP, WM. and YÁNÑEZARANCIBIA, A., 1989. Estuarine Ecology. New York: Wiley Interscience Publication.

DOLAN, JR. and MARRASÉ, C., 1995. Planktonic ciliate distribution relative to a deep chlorophyll maximum: Catalan Sea, NW Mediterranean June 1993. Deep-Sea Res. Part I, vol. 42, no. 11-12, p. 1965-1987.

DOLAN, JR. and GALLEGOS, C., 2001. Estuarine diversity of tintinnids (planktonic ciliates). J. Plankton Res., vol. 23, no. 9, p. $1009-1027$.

ESKINAZI-LEÇA, E., KOENING, ML. and SILVA-CUNHA, MGG., 2000. O fitoplâncton: estrutura e produtividade. In BARROS, HM., ESKINAZI-LEÇA, E., MACEDO, SJ. and LIMA, T. (Orgs.). Gerenciamento Participativo de Estuários e Manguezais. Recife: Editora Universitária UFPE. p. 67-74.

ESKINAZI-SANT'ANNA, EM. and TUNDISI, JG., 1996. Zooplâncton do estuário do Pina (Recife, Pernambuco, Brasil): composição e distribuição temporal. Rev. Bras. Oceanog., vol. 44 , no. 1 , p. 23-33.

ESKINAZI-SANT'ANNA, EM. and BJORNBERG, TKS., 2006. Seasonal dynamics of microzooplankton in the São Sebastião Channel (SP, Brazil). Braz.. J. Biol.= Rev. Bras. Biol., vol. 66 , no. 1b, p. 221-231.

FENCHEL, T., 1980. Relation between particle size selection and clearance in suspension-feeding ciliates. Limnol.Oceanogr., vol. 25 , no. 4 , p. $733-738$.

FORNERIS, L., SANTOS, MA., BARROS, AF., CABRAL, C., ROCHA, CEF., ARAÚJO, CS. and ALMEIDA, MRS., 1977. Estudo ecológico do estuário do Rio Sergipe. In: Reunião anual da SBPC, 1977, São Paulo. Ciênc. Cult., vol. 29, no. 7, p. 492.

GISMERVIK, I., OLSEN, Y. and VADSTEIN, O., 2002. Microand mesozooplankton response to enhanced nutrient input - a mesocosm study. Hydrobiol., vol. 484, no. 1-3, p. 75-87.

GODHANTARAMAN, N. and UYE, S., 2003. Geographical and seasonal variations in taxonomic composition, abundance and biomass of microzooplankton across a brackish-water lagoonal system of Japan. J. Plankton Res., vol. 25, no. 5, p. $465-482$.

HARLEMAN, DRF., 1979. Estudo de dispersão dos efluentes da fábrica de amônia-uréia da Petrobrás Fertilizantes S.A., no Rio Sergipe. Aracaju: CDTN; Nuclebrás; Petrobrás, 69 p. Technical report.

IBGE - Instituto Brasileiro de Geografia e Estatística, 2000. Censo demográfico 2000. Primeiros resultados da amostra. Rio de Janeiro. 519 p.

JICA, 1998. The Study on Water Resources Development in the State of Sergipe. [S.I.]: JICA; SEPLANTEC; Yachiyo Engineering Co. Ltd, 166 p. (Progress Report (1), December 1998).

LAM, CWY. and HO, KC., 1989. Red tides in Tolo Harbour, Hong Kong. In OKAICHI, T., ANDERSON, DM. and
NEMOTO, T. (Eds.). Red Tides: Biology, Environmental Science and Toxicology. New York: Elsevier. p. 49-42.

LANDRY, MR. and HASSETT, RP., 1982. Estimating the grazing impact of marine micro-zooplankton. Mar. Biol., vol. 67 , no. 3 , p. $283-288$.

LOPES, RM., 1994. Zooplankton distribution in the Guaraú river estuary (South-eastern Brazil). Est. Coast. Shelf Sci., vol. 39 , no. 3, p. 287-302.

LOPES, RM., ALMEIDA PRADO-POR, MS. and POR, FD., 1986. Zooplankton seasonality in the Rio Verde estuary. Rev. d'Hydrobiol. Trop., vol. 19, no. 3-4, p. 207-214.

MAGAlHÃES, A., COSTA, RM., LIANG, TH., PEREIRA, LCC. and RIBEITO, MJS., 2006. Spatial and temporal distribution in density and biomass of two Pseudodiaptomus species (Copepoda: Calanoida) in the Caeté river estuary (Amazon region - North of Brazil). Braz. J. Biol. $=$ Rev. Bras. Biol., vol. 66, no. 2a, p. 421-430.

MAGUIRE, B., 1973. Niche response structure and the analytical potentials of its relationship to the habitat. Am. Nat., vol. 107 , no. 954 , p. 213-246.

MARSHALL, SM., 1969. Protozoa, order Tintinnida. In FRASER, JH. and HANSEN, VK. (Eds.). Fiches d'Identification $d u$ Zooplankton. Copenhagen, Denmark: Conseil International pour l'Exploration de la Mer. p. 117-127.

MATSUMURA-TUNDISI, T., 1972. Aspectos ecológicos do zooplâncton da região lagunar de Cananéia com especial referência aos Copepoda (Crustacea). São Paulo: Instituto de Biociências, Universidade de São Paulo. 191 p. [Tese de Doutorado].

MCLUSKY, DS. and ELLIOTT, M., 2004. The estuarine ecosystem: ecology, threats, and management. 3 ed. New York: Oxford University Press.

MORGAN, SG., 1990. Impact of planktivorous fishes on dispersal, hatching, and morphology of estuarine crab larvae. Ecology, vol. 71, no. 5, p. 1639-1652.

NASCIMENTO, SA. and ROCHA, CEF., 1994. Determinação da composição do zooplâncton em 4 (quatro) estuários de Sergipe - Nordeste do Brasil. Aracaju, SE. 40 p. (mimeo).

NEUMANN-LEITÃO, S., 1995. Resenha Literária Sobre Zooplâncton Estuarino no Brasil. Recife: Ed. Universitária. vol. 23, p. 25-53. (Trab. Oceanogr.Univ. Fed. PE).

NEUMANN-LEITÃO, S., GUSMÃO, LMO. and NASCIMENTO-VIEIRA, DA., 1992. Zooplâncton dos estuários dos rios Massangana e Tatuoca, Suape (PE - Brasil). Braz. Arch. Biol. Tech., vol. 35, no. 2, p. 341-360.

NEUMANN-LEITÃO, S., GUSMÃO, LMO., SILVA, TA. and NASCIMENTO-VIEIRA, DA., 1996. Variação diurna e sazonal do microzooplâncton do estuário do rio Paripe, Itamaracá - PE (Brasil). Braz. Arch. Biol. Tech, vol. 39, no. 2, p. 373-384.

NEUMANN-LEITÃO, S., GUSMÃO, LMO., SILVA, TA., NASCIMENTO-VIEIRA, DA. and SILVA, AP., 1999. Mesozooplankton biomass and diversity in coastal and oceanic waters off North-Eastern Brazil. Arch. Fish. Mar. Res., vol. 47, no. 2-3, p. 153-165.

NEUMANN-LEITÃO, S. and MATSUMURA-TUNDISI, T., 1998. Dynamics of a perturbed Estuarine Zooplanktonic 
Community: Port of Suape, PE, Brazil. Verh. Internat. Verein. Limnol., vol. 26, no. 3, p. 1981-1988.

PAERL, HW., 1997. Coastal eutrophication and harmful algal blooms: importance of atmospheric deposition and groundwater as "new" nitrogen and other nutrient sources. Limnol. Oceanogr., vol. 42, no. 5, part 2, p. 1154-1165.

PIELOU, EC., 1967. An introduction to Mathematical Ecology. New York: Wiley-Interscience. 286 p.

PIERCE, RW. and TURNER, JT., 1992. Ecology of planktonic ciliates in marine food webs. Rev. Aquat. Sci., vol. 6, no. 2, p. $139-181$.

PIERCE, RW. and TURNER, JT., 1993. Global biogeography of marine tintinnids. Mar. Ecol. Prog. Ser., vol. 94, no. 1, p. 11-26.

RESH, VH. and UNZICKER, JD., 1975. Water quality monitoring and aquatic organisms: the importance of species identification. J. Water Poll. Control, vol. 47, no. 1, p. 9-19.

ROCHA, CEF., 1978. Zooplâncton dos estuários dos Rios Sergipe e Japaratuba, Estado de Sergipe, Brasil. In $5^{\text {th }}$ Simpósio Latinoamericano sobre Oceanografia Biológica, São Paulo. São Paulo: IOUSP. p. 107-108.

SANDERS, RW., 1987. Tintinnids and other microzooplankton - seasonal distributions and relationships to resources and hydrography in a Maine estuary. J. Plankton Res., vol. 9, no. 3, p. $65-77$.

SANKARANKUTY, C., MEDEIROS, GF. and SANTOS, NQ., 1979. On diurnal variation of zooplankton in a tidal estuary. $J$. Mar. Biol. Ass. India, vol. 21, no. 1-2, p. 187-190.

SCHWAMBORN, R., 1997. The influence of mangroves on community structure and nutrition of macrozooplankton in northeast Brazil. ZMT Contrib., Bremen, vol. 4, p.1-77.

SCHWAMBORN, R., BONECKER, SLC., GALVÃO, IB., SILVA, TA. and NEUMANN-LEITÃO, S., 2004. Mesozooplankton grazing under conditions of extreme eutrophication in Guanabara Bay, Brazil. J. Plankton Res., vol. 26 , no. 9 , p. $983-992$

SCHWAMBORN, R., EKAU, W., VOSS, M. and SAINT-PAUL, U., 1999. Stable isotope composition of particulate organic matter and zooplankton in Northeast Brazilian shelf waters. Arch. Fish. Mar. Res., vol. 47, no. 2-3, p. 201-210.

SHANNON, CE., 1948. A mathematical theory of communication. Bell Syst. Tech. J., vol. 27, p. 379-423 and p. 623-656.
SILVA, AP., NEUMANN-LEITÃO, S., SCHWAMBORN, R., GUSMÃO, LMO. and SILVA, TA., 2004. Mesozooplankton of an impacted bay in North Eastern Brazil. Braz. Arch. Biol. Tech., vol. 47, no. 3, p. 485-493.

SILVA, T., NEUMANN-LEITÃO, S., SCHWAMBORN, R., GUSMÃO, LMO. and NASCIMENTO-VIEIRA, DA., 2003. Diel and seasonal changes in the macrozooplankton community of a tropical estuary in Northeastern Brazil. Rev. Bras. Zool., vol. 20 , no. 3 , p. $439-446$.

SOROKIN, YI., 1995. Role of plankton in the turnover of organic matter on the Great Barrier Reef, Australia. Hydrobiol., vol. 308 , no. 1 , p. $35-44$.

SOUZA, MFL., 2000. DIN, DIP Budgets for Rio Sergipe, Sergipe State. Available from: http://data.ecology.su.se/mnode/ South\%20America/Sergipe/rio_sergipebud.htm.

STRICKLAND, JDH. and PARSONS, TRA., 1965. A manual of seawater analysis. Bull. Fish. Res. Board Can., vol. 125, p. 1-205.

TER BRAAK, CJF. and SMILAUER, P., 1998. CANOCO Reference Manual and User's Guide to Canoco for Windows: Software for Canonical Community Ordination. Version 4. Ithaca, NY USA: Microcomputer Power. 352 p.

TER BRAAK, CJF., 1989, CANOCO - an extension of DECORANA to analyze species-environment relationships. Hydrobiol., vol. 184, no. 3, p. 169-170.

TER BRAAK, CJF., 1986. Canonical correspondence analysis: a new eigenvector technique for multivariate direct gradient analysis. Ecology, vol. 67, no. 5, p. 1167-1179.

TILLMANN, U., 2004. Interactions between planktonic microalgae and protozoan grazers. J. Eukaryotic Microbiol., vol. 51 , no. 2, p. 156-168.

TUNDISI, JG., 1970. O plâncton estuarino. Contrib. Avul. Inst. Oceanogr. São Paulo, série Oceanografia Biológica, São Paulo, Brazil, vol. 19, p. 1-22.

URRUTXURTU, I., 2004. Seasonal succession of tintinnids in the Nervión river estuary, Basque Country, Spain. J. Plankton Res., vol. 26, no. 3, p. 307-314.

VERITY, PG., 1987. Abundance, community composition, size distribution, and production rates of tintinnids in Narragansett Bay, Rhode Island. Est. Coast. Shelf Sci., vol. 24, no. 5, p. 671-690.

ZAR, JH., 1990. Biostatistical analysis. 2 ed. New Jersey: Prentice Hall. 718 p. 